\title{
SELECTION OF SUSTAINABLE SUPPLIER(S) IN A PAINT MANUFACTURING COMPANY USING HYBRID META- HEURISTIC ALGORITHM
}

\author{
M.G.K Machesa ${ }^{1}$, L.K. Tartibu ${ }^{1} \&$ M.O. Okwu ${ }^{1 *}$
}

\section{ARTICLE INFO}

Article details

Presented at the $31^{\text {st }}$ annual conference of the Southern African Institute for Industrial Engineering (SAllE), held virtually from 5-7 October 2020 .

Available online $\quad 11$ Nov 2020

Contact details

* Corresponding author

mechanicalmodestus@yahoo.com

\section{Author affiliations}

1 Department of Mechanical and Industrial Engineering, University of Johannesburg, South Africa

ORCID identifiers

M.G.K. Machesa

https://orcid.org/0000-0002-3218-1825

L.K. Tartibu

https://orcid.org/0000-0003-2111-7155

M.O. Okwu

https://orcid.org/0000-0002-7761-9659

DOI

http://dx.doi.org/10.7166/31-3-2429
ABSTRACT

Supplier selection in a manufacturing system is highly complex owing to the nature and structure of organisations, necessitating a paradigm shift from the rule-of-thumb and classical methods of supplier selection to a reliable technique that uses a hybrid algorithm to provide greater accuracy in the selection process. This study proposes the use of a hybrid computational intelligence technique - an adaptive neuro-fuzzy inference system - for the effective identification and selection of sustainable suppliers. This hybrid modelling configuration was applied in a paint manufacturing company to select the best possible supplier. Information obtained from the company within the period of investigation was fed into the model. The result obtained shows a faster and more reliable prediction by the creative model. Professionals and business managers will benefit greatly from the selection of sustainable suppliers in an in-bound and outbound supply chain system.

\section{OPSOMMING}

Verskaffer seleksie in 'n vervaardigingstelsel is hoogs ingewikkeld as gevolg van die aard en struktuur van organisasies. 'n Paradigmaskuif weg van die duimreël- en ander klassieke benaderings is nodig om ' $n$ betroubare tegniek, wat gebruik maak van 'n hibriede algoritme vir beter akkuraatheid tydens die seleksieproses, te verskaf. Die gebruik van 'n hibriede berekening intelligensie tegniek - 'n aanpasbare neuro-wasige inferensie stelsel - word voorgestel vir die doeltreffende identifisering en kies van volhoubare verskaffers. Die hibriede modelleringkonfigurasie is toegepas in 'n verf vervaardigingsmaatskappy om die beste moontlike verskaffer te kies. Die resultaat was 'n vinniger en meer betroubare voorspelling deur die kreatiewe model. Beroepsmense en besigheidsbestuurders sal baat vind by die kies van volhoubare verskaffers in 'n voorsienningskettingstelsel.

\section{INTRODUCTION}

In a bid to minimise cost and improve the quality of services, manufacturing companies have benefited from outsourcing resources and many of their manufacturing processes to other companies. This resolution has presented paint manufacturing companies with numerous unfamiliar challenges [1]. An analysis by Accenture Consulting revealed that 80 per cent of the companies that responded drew their services and inventory from third-party providers, and allocated more than half of their funds to outsourcing [2]. The importance of selecting an ideal supplier has become significant in modern organisations. Many researchers have considered the selection of a suitable and sustainable supplier as one of the most critical operational activities, and as a central factor in drastically improving sustainable supply chain management.

A sustainable supplier integrates environmental, financial, and social aspects into their dealings [3]. The idea of sustainability has gained significant traction among researchers. This has been motivated by the need to protect natural resources and to maintain a balance between the profits generated and the social duties of companies. The identification and selection of an ideal and sustainable supplier can give a company competitive advantage in reducing operating costs, improving the quality of its goods, and being able to to offer improved services to its clientele [1]. The acknowledged steps in evaluating and selecting 
a sustainable supplier have expanded greatly from a peripheral view based only on a price orientation. More organisations are required to have suitable and precise assessment techniques to identify suppliers that will meet the company's requirements and realise sustainability in the distribution network [3]. Additional factors - such as environmental implications, economic influences, supplier activities, characteristics, and social criteria - should be used during the process of evaluating the fit of a sustainable supplier to enhance performance and to achieve true sustainability in the supply chain. Several standards and measurements must therefore be applied in the evaluation process [2]. Several authors have discussed supplier selection issues while considering the social and sustainability aspects. Ghoushchi, Milan and Rezaee [4] described sustainable supplier selection criteria in a table format. Table 1 shows the general standards used to identify sustainable suppliers.

Table 1: Common criteria used to evaluate sustainable suppliers [4]

\begin{tabular}{|l|l|}
\hline Category & Measures \\
\hline Social & $\begin{array}{l}\text { The moral or legal entitlement of the workers, the interest of associates, company safety and } \\
\text { welfare, corrective and security procedures, declaring correct information, preserving good } \\
\text { character, abiding by local rules, facilitating training }\end{array}$ \\
\hline Economic & $\begin{array}{l}\text { Competitive costs, quality service, technological know-how, organisation and management, } \\
\text { production capabilities, strong financial muscle, high reliability, flexibility, delivery time, } \\
\text { originality }\end{array}$ \\
\hline Environmental & $\begin{array}{l}\text { Environmental costs, eco-friendly design, environmental impact analysis, environmental } \\
\text { appropriateness, green research and development capabilities, number of ISO standards obtained, } \\
\text { minimal pollution, green products, management of resource utilisation, strategies minimising the } \\
\text { use of ozone-exhausting chemicals, salvaging plans, water consumption, renewable energy }\end{array}$ \\
\hline
\end{tabular}

To meet the criteria described above, a detailed quantitative unit may not be practical, as some of the information is cardinal or ordinal [4]. A suitable decision-making model is thus required. Several methods have been proposed to solve the issues in supply chain management effectively. Practices such as analytic hierarchy process (AHP), technique for order of preference by similarity to ideal solution (TOPSIS), artificial neural networks (ANN), analytic network process (ANP), case-based reasoning (CBR), and mathematical programming approaches such as data envelopment analysis (DEA) and fuzzy set theory (FST) have been used in the various reviews [4]. Another technique that can be implemented for performance assessment and the selection of a sustainable supplier is the adaptive neuro-fuzzy inference system (ANFIS).

ANFIS was introduced in 1993 by Jyh-Shing Roger Jang to have the algorithm learn and achieve better performance in the presence of uncertainties [5]. The hybrid system has an arrangement that integrates the qualitative and sensitivity rules of fuzzy logic with the self-taught capabilities of neural networks that can adapt and comprehend the fuzzy inference system. The rule viewer is created with well-defined rules and membership functions of fuzzy inference model by converting input values proficiently into a targeted output value, and takes advantage of the set constraints from the fuzzy system that minimise the optimisation search space. The neural network is included to advance the performance through the automation of the fuzzy control parametric tuning by the adaptation of back-propagation to structure the network [5]. The present paper proposes ANFIS as a technique to assess and select the most suitable supplier for a paint manufacturing company. The paper contains the following sections: a review section describing the supplier selection process and the work conducted by other authors; a methodology and data collection section detailing the sustainability factors and the ANFIS algorithm and models; an analysis of the dataset; and the conclusions.

\section{SUPPLY CHAIN AND SUPPLIER SELECTION PROCESS}

Numerous researchers have investigated supply chain methodologies. The research indicates that there are clear differences between the operations of different companies. Each follows a unique methodology, and each has exclusive financial strategies and a reputation in the eyes of its clients. This suggests that, in various organisations, the supplier selection process can be executed in alternative ways. [6]. This section presents details of the work of other researchers to define the supplier selection process.

Webster and Wind [7] attempted to classify the essential requirements of a company during the selection procedure. The model was intended to incorporate the selection process in a system without trying to determine each progression in the entire procedure. The steps can alter the process of selection, as numerous components affect the purchasing conduct - for example, individual preferences, social dynamics, environment, and economic climate. De Boer, Van der Wegen and Telgen [8] presented a supplier 
selection structure that suits a variety of circumstances in the supplier selection process. A summary of De Boer et al.'s supplier selection criteria is shown in Table 2.

Dobler and Burt [9] presented a supplier selection process, arguing that the method applied in all companies is similar. A flow of activities formulated by Dobler and Burt is shown in Figure 1.

Table 2: A supplier selection model (adapted from De Boer [8])

\begin{tabular}{|c|c|c|c|c|}
\hline & New task & $\begin{array}{l}\text { Modified re-buy } \\
\text { (leverage items) }\end{array}$ & $\begin{array}{l}\text { Straight re-buy } \\
\text { (routine Items) }\end{array}$ & $\begin{array}{l}\text { Straight re-buy } \\
\text { (bottleneck) }\end{array}$ \\
\hline $\begin{array}{l}\text { Problem } \\
\text { definition }\end{array}$ & $\begin{array}{l}\text { Select supplier for } \\
\text { use or not? } \\
\text { Varying importance } \\
\text { Once-off decision }\end{array}$ & $\begin{array}{l}\text { Use more, fewer, or } \\
\text { other suppliers? } \\
\text { Moderate/high } \\
\text { importance } \\
\text { Repeat decision }\end{array}$ & $\begin{array}{l}\text { Change the existing } \\
\text { suppliers? } \\
\text { Low/moderate } \\
\text { importance } \\
\text { Repeat decision }\end{array}$ & $\begin{array}{l}\text { How to deal with the } \\
\text { suppliers? } \\
\text { High importance } \\
\text { Repeat evaluation }\end{array}$ \\
\hline $\begin{array}{l}\text { Formulation of } \\
\text { criteria }\end{array}$ & $\begin{array}{l}\text { Historical } \\
\text { information on } \\
\text { suppliers not } \\
\text { accessible } \\
\text { No previously used } \\
\text { criteria available } \\
\text { Varying importance }\end{array}$ & $\begin{array}{l}\text { Existing historical } \\
\text { information on } \\
\text { suppliers } \\
\text { Previously used } \\
\text { criteria accessible }\end{array}$ & $\begin{array}{l}\text { Existing historical } \\
\text { information on } \\
\text { suppliers } \\
\text { Previously used } \\
\text { criteria accessible }\end{array}$ & $\begin{array}{l}\text { Existing historical } \\
\text { information on suppliers, } \\
\text { yet very few selections } \\
\text { Previously used criteria } \\
\text { accessible }\end{array}$ \\
\hline Qualification & $\begin{array}{l}\text { Small set of } \\
\text { suppliers } \\
\text { Sorting rather than } \\
\text { ranking } \\
\text { No historical records } \\
\text { available }\end{array}$ & $\begin{array}{l}\text { Bigger set of } \\
\text { suppliers } \\
\text { Sorting and ranking } \\
\text { Historical data } \\
\text { accessible }\end{array}$ & $\begin{array}{l}\text { Bigger set of } \\
\text { suppliers } \\
\text { Sorting and ranking } \\
\text { Historical data } \\
\text { accessible }\end{array}$ & $\begin{array}{l}\text { Very small set of } \\
\text { suppliers } \\
\text { Sorting rather than } \\
\text { ranking } \\
\text { Historical data accessible }\end{array}$ \\
\hline Choice & $\begin{array}{l}\text { Small set of } \\
\text { suppliers } \\
\text { Ranking rather than } \\
\text { sorting } \\
\text { Many criteria } \\
\text { Much interaction } \\
\text { Varying importance } \\
\text { Model used once }\end{array}$ & $\begin{array}{l}\text { Small to moderate } \\
\text { set of suppliers } \\
\text { Ranking rather than } \\
\text { sorting } \\
\text { Also: how to allocate } \\
\text { volume? } \\
\text { Fewer criteria } \\
\text { Less interaction } \\
\text { Model used again }\end{array}$ & $\begin{array}{l}\text { Small to moderate } \\
\text { set of suppliers } \\
\text { Ranking rather than } \\
\text { sorting } \\
\text { Fewer criteria } \\
\text { Less interaction } \\
\text { Model used again } \\
\text { Single sourcing rather } \\
\text { than multiple } \\
\text { sourcing }\end{array}$ & $\begin{array}{l}\text { Very small set of } \\
\text { suppliers (often only one) } \\
\text { Assessing rather than } \\
\text { selecting } \\
\text { Sole sourcing }\end{array}$ \\
\hline
\end{tabular}

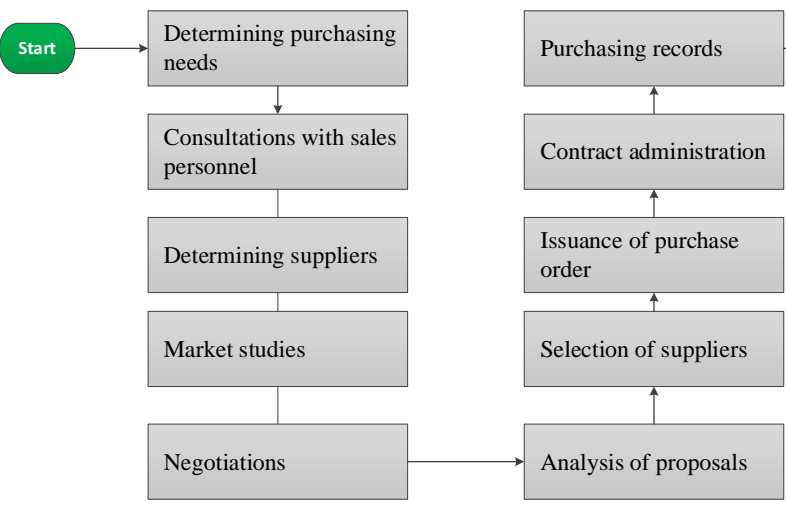

Figure 1: An all-inclusive selection process [9]

Monczka, Handfield, Giunipero and Patterson [10] argued that the supply chain process requires consistent development to identify the prerequisites. They stated that, for a company to be successful, a regular assessment of the organisation's needs, identification of ideal suppliers, measuring supplier execution 
performance, guaranteeing that compensation occurs within the given timeframes, constant improvement should be carried out periodically. One of the key points of the examination was to determine the organisation's buying obligations, the measures to reach the necessary goals and guidelines of the organisation, the techniques to assess the performance, and the means to update plans to enhance the general performance of the supplier. The steps developed by Monczka et al. [10] include identifying critical supplier assessment classes, weighing all the measures, defining a scoring system, directly evaluating the supplier, reviewing the results of the evaluation to make a decision, and reviewing the supplier's performance.

Van Weele [11] argued that supplying capacity alluded to the operational action of the supplying procedure. The author presented the idea of a supply chain model that incorporates six principles. These principles decide the quality and the amount of merchandise planned for purchase; the choice of the ideal distributor; changes to the agreement conditions and legal matters among the parties; the authorising, speeding up, and assessment that has a place with checking and controlling the suppliers, and the investigation that is linked to resolving claims; and the management of records, provider ratings, and review positioning. Cousins [12] formulated four stages related to the decision of a key supply selection process to build the degree of significance in the value chain. During the main stage, called 'initial supplier qualification', a company needs to choose and limit the possible distributors that qualified by meeting the required minimum standards, which can be detailed as the quality of the item, the definite requirements, and the capacity to sustain continuous support. The requisition of price estimations, demand for a proposition, and requests for data are the best-known strategies for getting information from suppliers. The next stage is to distinguish the measuring criteria. One approach to assessing the standards is to measure suppliers against the cost, and to find a balance between the supposed quality and the total cost.

\subsection{Research on supplier selection}

Distinctive strategies, or a blend of techniques, have been made available to help companies with their supplier assessment and selection. For a company to build sustainably efficient controls and to ensure that the customer is satisfied, an exceptional relationship with suppliers is needed. To reduce costs and offer better types of support, companies should try to outsource some portion of their inventory or administration. Companies thus consider supplier evaluation and determination techniques. It would be a hopeless endeavour to compete in serious markets if organisations considered only one measure rather than numerous factors. Ecer and Pamucar [13] proposed a structure that integrated the fuzzy best-worst method (F-BWM) and fuzzy combined compromise solution ( $\mathrm{F}-\mathrm{CoCoSo}$ ) with the Bonferroni multi-criteria model to assess providers for their sustainability, even with in the presence of uncertainties in the dynamic procedure and an absence of quantitative data. The proposed network enables users to adjust the weights of different variables that are used to evaluate the best fit when choosing a sustainable supplier, and so highlights the importance of various facets of sustainability. The system successfully managed to generate targeted outputs. Abdolazimi, Esfandarani, Salehi and Shishebori [14] established a three-objective mixedinteger linear modelling tool to optimise the time it takes for products to be delivered, the environmental factors, and the overall profit. Mulvey, Vanderbei and Zenios [32] methods are used to minimise the uncertainties of the parameters in the model. Implementation of the model was conducted in the supplier selection of a tyre company. The model was successful in evaluating and selecting the best supplier. Luthra et al. [15] worked on techniques and models for assessing suppliers, and proposed 22 measurements for the supplier selection assessment in an Indian vehicle organisation. The authors weighed the models using the scientific chain of importance, and evaluated the providers using the VIKOR procedure. This was accomplished by combining the fluffy Shannon entropy method and the fluffy interference framework.

\section{METHODOLOGY}

This research study is intended to demonstrate the procedure for the selection of sustainable suppliers for a paint manufacturing company. This is achievable by noting the sustainability factors and rating the semantic attributes using alpha cuts from the ANFIS rule viewer using the MATLAB toolbox. The main objective of this research is to implement a hybrid algorithm to predict the best possible suppliers, considering input variables obtained from a paint manufacturing company. For each input variable, multiple membership functions (MFs) are considered.

\subsection{ANFIS Algorithm}

An ANFIS algorithm was implemented in this research for the effective estimation and prediction of feasible and justifiable suppliers considering a proven sustainability factor. Hybrid traditional algorithms and other computational techniques have previously been used by scholars [17-28]. ANFIS has demonstrated superior 
strength compared with techniques such as TOPSIS, ANN, and FUZZY [16,29]. A hybrid algorithm adaptive neuro-fuzzy inference system was used in this research owing to its superior and expressive power to examine the relationships between the input variables and possible suppliers. The ANFIS architecture described by Abdulshahed, Longstaff and Fletcher [31] is shown in Figure 2. The ANFIS algorithm has the superior power of sectioning the input variables fed into the Matlab platform to form membership functions for easy mapping, as shown in Figure 3. The figure presents a membership function plot for variables in terms of sustainability factors ranging from one to ten MFs, with plots being initiated on the left-hand side of the FIS variables in yellow boxes. The membership function, representing the suppliers, is shown in blue boxes ranging from one to four MFs, as shown in Figures 3 and 4 respectively. Mapping was done equally for all MFs.

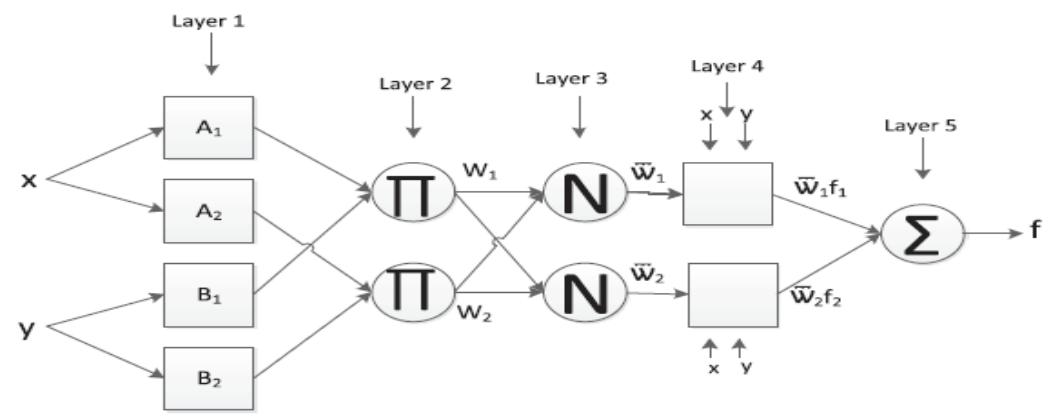

Figure 2: ANFIS structure of type 3, with two inputs and one output

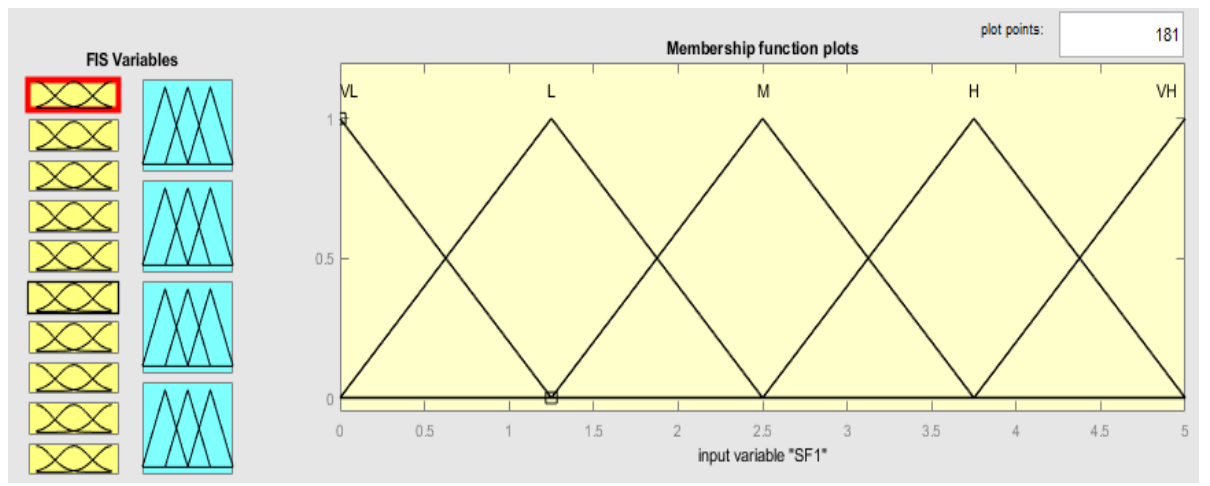

Figure 3: Membership function plots

\subsection{ANFIS model symbols}

$X$ and $Y$ represent the input from the external source to the network node in the first layer (i) $A$ and $B$ represent the connecting weight at the node, which is linked to the linguistic identifier $\mu(\mathrm{X} / \mathrm{Y})$ represents the membership function for easy mapping or plotting

$\mathrm{N}$ represents the normaliser or junction node

0 represents the output node for each network layer

$\Pi$ represents the layer obtainable at the second node

$W$ is the weighted strength or firing point of the strength of the network

$\bar{w}$ is the normalised point of strength for firing the network

$\mathrm{p}_{\mathrm{i}}, \mathrm{q}_{\mathrm{i}}$, and $\mathrm{r}_{\mathrm{i}}$ are set parameters of the model

$f_{1}$ and $f_{2}$ models represent the 'what-if/if-then' rules

$i$ represents the indexing for the input node

$$
\begin{gathered}
O_{1, i}=\mu_{A i}(X) \text { where } \mathrm{i} \text { denotes } 1,2 \\
O_{1, i}=\mu_{B i=2}(Y) \text { where } \mathrm{i} \text { denotes } 3,4
\end{gathered}
$$




$$
\begin{gathered}
O_{2, i}=w_{i}=\mu_{A i}(X) \cdot \mu_{B i=2}(\mathrm{Y}) \text { i denotes } 1,2 \\
O_{3, i}=\bar{w}=\frac{w_{i}}{w_{1}+w_{2}}, \mathrm{i} \text { is equal to } 1,2 \\
O_{4, i}=w_{i} \cdot f_{i} \text { for } \mathrm{i}=1,2 \\
O_{5, i}=\sum_{i} \bar{w}_{i} \cdot f_{i}=\frac{\sum_{i} w_{i} f_{i}}{w_{i}}=f_{\text {out }}=\text { overall output }
\end{gathered}
$$

where $f_{1}$ and $f_{2}$ are the fuzzy 'what-if' or 'if-then' rules, and are as follows:

Rule 1: IF $X$ is represented by $A_{1}$ and $Y$ represents $B_{1}$, THEN $f_{1}$ is equal to $p_{1} X+q_{1} Y+r_{1}$ Rule 2: IF $X$ is represented by $A_{2}$ and $Y$ represents $B_{2}$, THEN $f_{2}$ is equal to $p_{2} X+q_{2} Y+r_{2}$ where $p_{i}, q_{i}$, and $r_{i}$ are already defined

\subsection{Case study}

The company used as a case study was a paint manufacturing company with two major transshipment points and sixteen destination centres. Primary and secondary modes of data were sourced in this research. A questionnaire was drafted to obtain accurate information from the respondents; direct information was obtained from operational and strategic staff of the company; and interaction with customers at various locations also helped to obtain accurate and adequate information. In this research, four suppliers were considered (S1-S4). Criteria of considerable importance were listed as sustainability factors (SF). Then the selected SFs were: quality (SF1); on-time delivery (SF2); reliability (SF3); price/value (SF4); performance history (SF5); technical capability (SF6); packaging (SF7); warranty and claim policies (SF8); availability (SF9); and customer service (SF10).

Table 3: Suppliers' performance with respect to sustainability factors

\begin{tabular}{lllll}
\hline Sustainability factors & $\mathrm{S} 1$ & $\mathrm{~S} 2$ & $\mathrm{~S} 3$ & $\mathrm{~S} 4$ \\
\hline $\mathrm{SF}_{1}$ & 3 & 5 & 2 & 4 \\
$\mathrm{SF}_{2}$ & 3 & 3 & 2 & 4 \\
$\mathrm{SF}_{3}$ & 4 & 5 & 4 & 5 \\
$\mathrm{SF}_{4}$ & 3 & 3 & 5 & 3 \\
$\mathrm{SF}_{5}$ & 4 & 4 & 4 & 4 \\
$\mathrm{SF}_{6}$ & 4 & 4 & 5 & 5 \\
$\mathrm{SF}_{7}$ & 3 & 5 & 2 & 5 \\
$\mathrm{SF}_{8}$ & 3 & 5 & 1 & 5 \\
$\mathrm{SF}_{9}$ & 2 & 4 & 1 & 4 \\
$\mathrm{SF}_{10}$ & 3 & 3 & 3 & 5 \\
\hline
\end{tabular}

The supplier performance in relation to the retail industry-related sustainability factors was translated and summarised on the questionnaire, as presented in Table 3. The results obtained - based on information gathered from the respondents about the suppliers - are represented using the linguistic scale in Table 4.

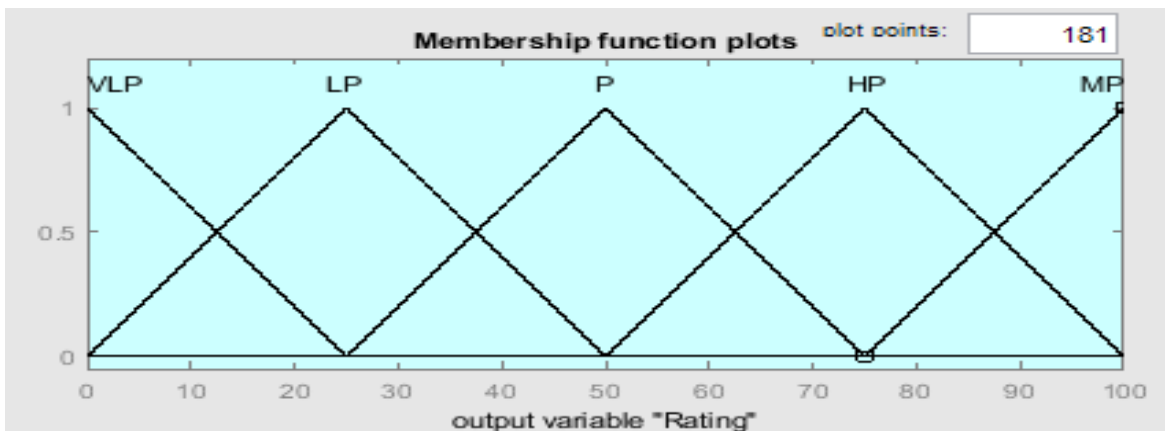

Figure 4: Rating for output variables to predict best supplier

The terms shown in Table 4 were chosen for each variable and factor to display the degree of each input for an effective rating of the best supplier. In this study, the degree of membership is defined as between 0 and 1. ANFIS rules using the ' $\mathrm{IF}^{\prime}$ ' and 'THEN' conditions were used in the study from the rule editor to define the relationships between the parameters of the fuzzy logic system, created by the hybrid technique with the help of the questionnaire responses in the rule editor. Multiple MFs are considered for effective analysis, considering the selected input variables, and using the triangular membership functions for all variables. 
Table 4: Linguistic scale for ANFIS input MFs

\begin{tabular}{ll}
\hline Semantic attributes & Corresponding values \\
\hline Very high & 5 \\
High & 4 \\
Moderate & 3 \\
Low & 2 \\
Very low & 1 \\
\hline
\end{tabular}

Table 5: Linguistic scale for ANFIS output MF rating

\begin{tabular}{ll}
\hline ANFIS linguistic term & Assigned values \\
\hline Most preferred (MP) & $80-100$ \\
Highly preferred (HP) & $60-79$ \\
Preferred (P) & $40-59$ \\
Low preference (LP) & $20-39$ \\
Very low preference (VLP) & $0-19$ \\
\hline
\end{tabular}

A framework was built for the entire in-bound sustainable supplier selection arrangement, as shown in Figure 5. The structure is a collection of ten input variables and four suppliers. To demonstrate effectively the predictive ability of the hybrid algorithm as a creative technique, an ANFIS toolbox was called from MATLAB and the data set was keyed into the ANFIS platform to appraise the suppliers effectively.

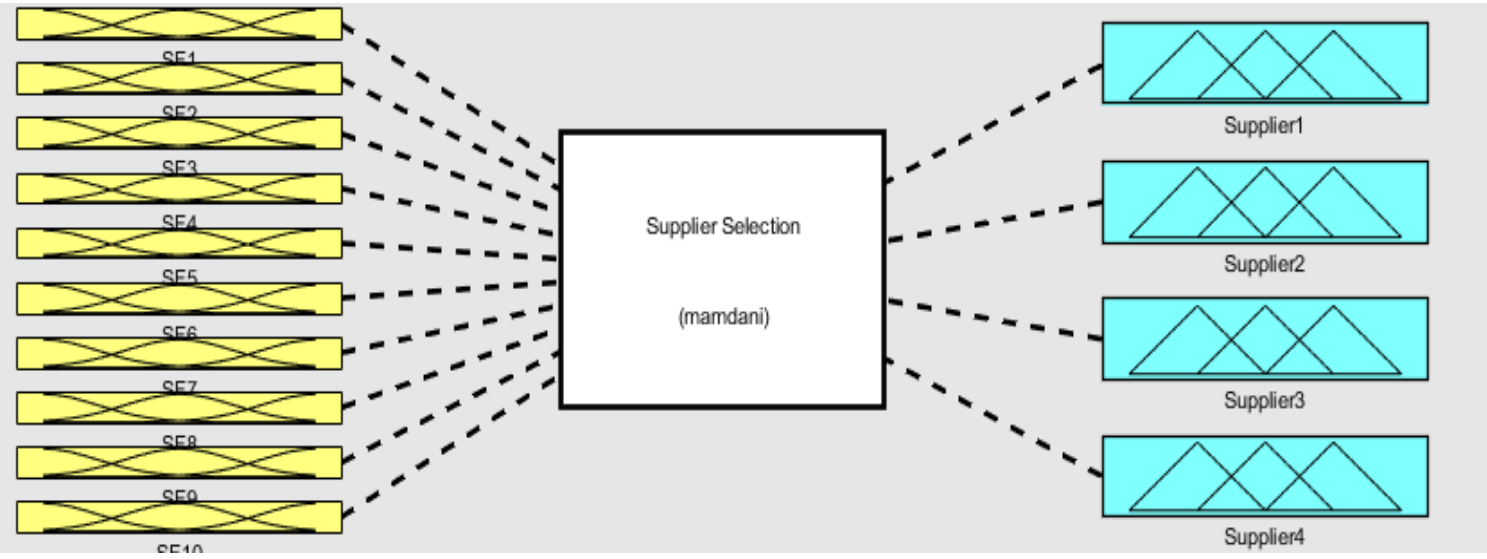

Figure 5: Structural view of the ANFIS platform with ten input variables and four suppliers

A well-structured ANFIS network architecture with common logical operations and a clear plot of the hybrid algorithm is shown in Figure 6. The black and white nodes represent the input and output membership functions, while the blue colour nodes represent the developed rules. ANFIS automatically generated 200 rules. The training process was performed several times, and the best ANFIS training was obtained around epoch fifteen (15) with minimal testing and validation errors. The controller used for the decision-making process in the ANFIS toolbox is the sigmoid function, using triangular membership functions (MFs) for the input / output dataset available (see Figures 3 and 4 for the triangular membership function for ten input variables used in this analysis, which is plotted based on the dataset obtained from the paint company).

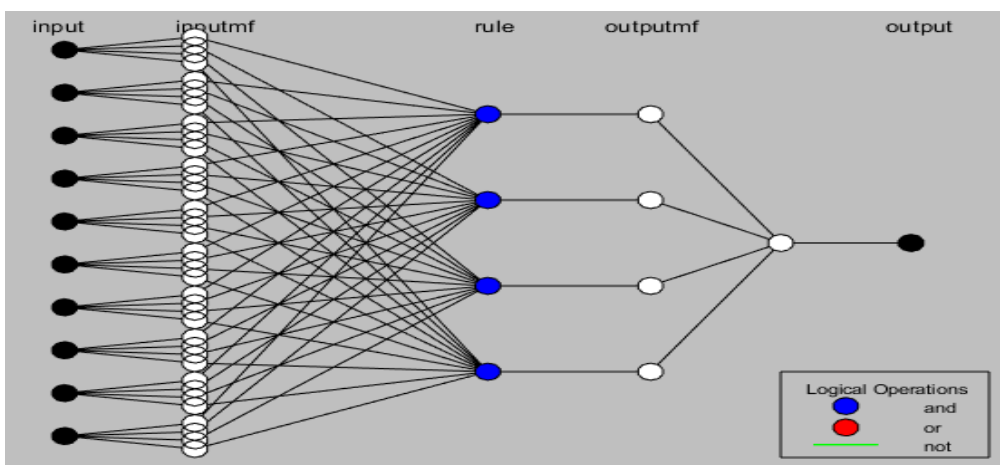

Figure 6: ANFIS architecture with logical operations for easy rule development 
The training process was performed repeatedly using the ANFIS toolbox, and the system automatically generated rules from the available information from fuzzy inference variables and the membership function design. The system repeatedly generated output results, which are displayed in blue colour lines, as shown in Figures 7 to 10. As illustrated in the figures, each rule shows a row of plots from the decision variables. The system automatically generated the output solutions, presented in the right hand column of the figures. This is possible by shifting the red line left or right to obtain accurate output predictions or ratings in the current analysis for the ten input variables. The model established 10 to the power of 4 possible fuzzy rules for each variable by considering the fuzzy linguistic rules and the assigned value for the effective prediction of the best justifiable supplier from among the existing suppliers.

To determine the performance of suppliers with respect to suitable input variables for the sustainability features, the ANFIS toolbox serves as the indicator for a solution response, by alpha cutting and refining weights using the rule viewer platform displayed with the available data set in the figures. From the ANFIS sensitivity analysis using the rule viewer established from the ANFIS algorithm, the best rating from the rule viewer is shown on the right-hand side of Figures $7,8,9$, and 10 in blue colour mapping.

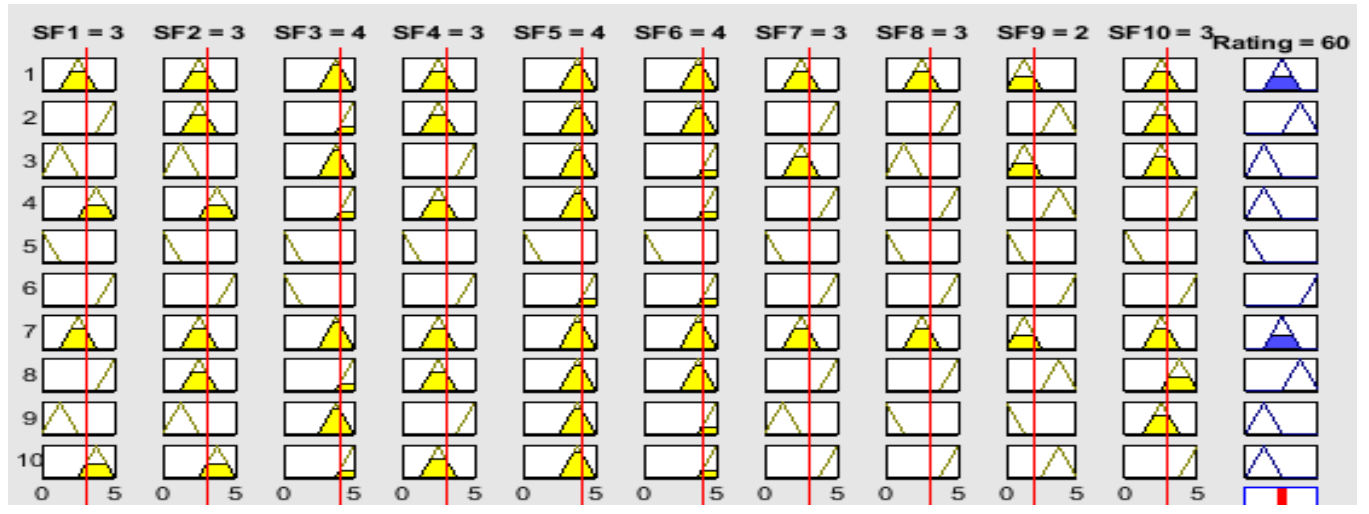

Figure 7: Rule viewer for ANFIS solution for supplier 1

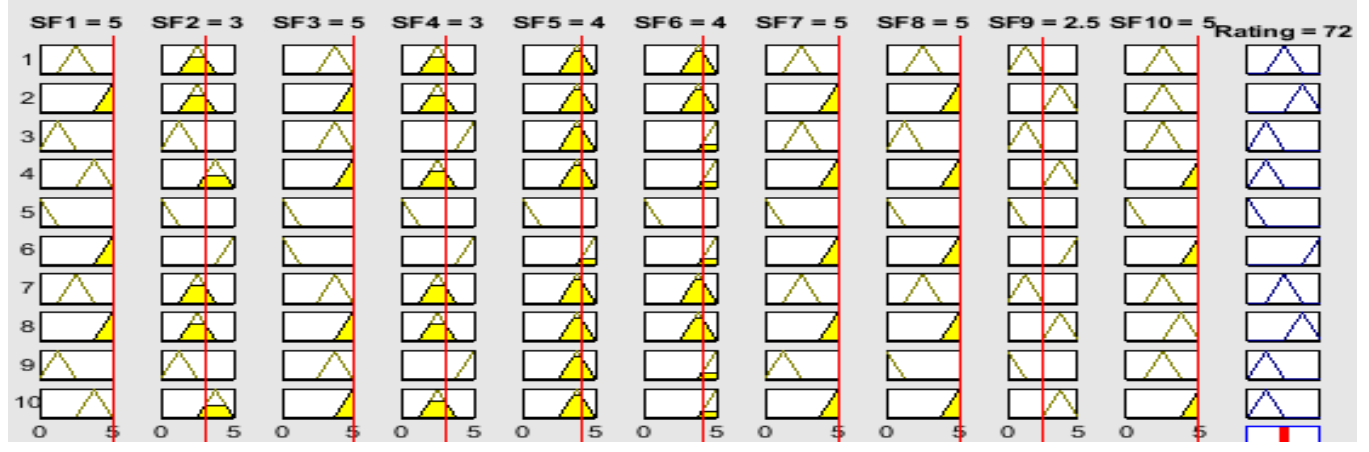

Figure 8: Rule viewer for ANFIS solution for supplier 2

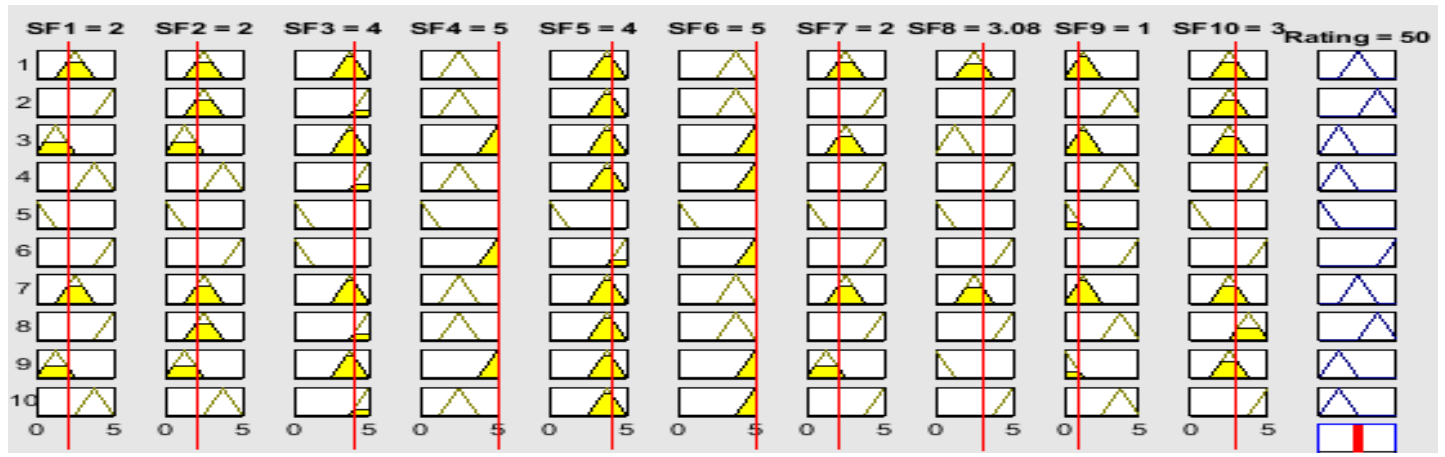

Figure 9: Rule viewer for ANFIS solution for supplier 3 

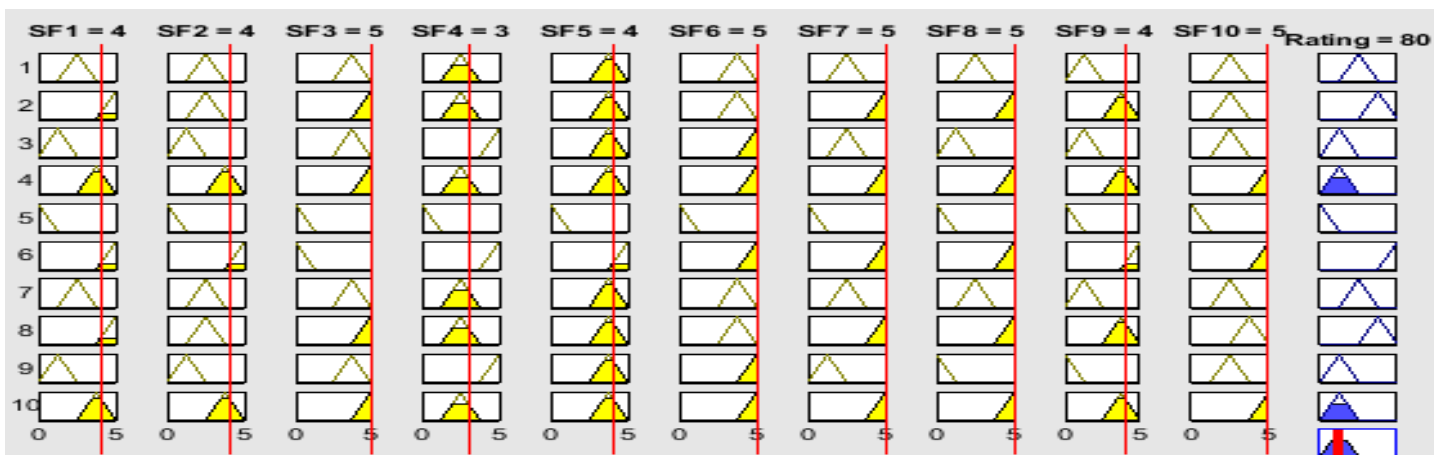

Figure 10: Rule viewer for ANFIS solution for supplier 4

\section{ANALYSIS AND DISCUSSION}

To determine the choice or the preferred groups for assessing the various suppliers' performances, decisionmakers in the paint manufacturing company make use of hybrid computational intelligence with respect to the sustainability factors. Once the rule structure had been analysed in the system, the category of choice was assigned to specify the levels of preference. The creative model of the hybrid ANFIS model was analysed effectively using the established ANFIS solution rule viewer, as shown in the setup in Figures 7 to 10 . It is important to note that the value range of 0-19 was assigned to the 'very low' group, the value range of 2039 was assigned to the 'medium' group, the value range of 40-59 was assigned to the 'preferred' group, the value range of 60-79 was assigned to the 'highly preferred' group, and the value range of 80-100 was assigned to the 'most desired' group, as shown in Table 5. The viewer of the ANFIS hybrid model was tuned and updated using the red colour lines, based on the information received. The solution rule viewer - as shown in Figure 7, which indicates that supplier 1 has a ranking value of 60 - falls within the assigned 'highly preferred' category of choice. Equally, by setting the input parameters in red colour lines, Figure 8 specifies that supplier 2 has a ranking value of 72 , which also fall into the 'highly preferred' group of options. Figure 9 provides that supplier 3 has a ranking value of 50, which fall into the 'preferred' option group; and finally, Figure 10 indicates that supplier 4 has a ranking value of 80 , which fall into the 'most preferred' option group. Based on the results of the ANFIS analysis, as presented on the toolbox platform, the best rating for a sustainable supplier for the paint manufacturing company is that of Supplier 4. This research finding is in line with the study conducted by Okwu and Tartibu [16], where ANFIS and TOPSIS were successfully implemented in the selection of sustainable suppliers for fast-moving consumer goods. This is a clear indication that this hybrid algorithm is highly effective and can be applied in any productbased system where raw materials are required for the production process. Based on the results of this report, the supply managers of the paint manufacturing company were given recommendations to concentrate on the most significant sustainability factors for achieving high product quality while maintaining good customer relationships in support of the growth of the company. This work is also expected to provide academics, policymakers, and retail industry practitioners with in-depth insights.

\section{CONCLUSION}

High-quality products and customer satisfaction are expected from every manufacturer in a competitive and dynamic environment. The selection of sustainable suppliers (SSS) is the first step in the process of producing high quality products and maintaining good relationships with customers. It is a critical attribute for manufacturers who want to succeed in establishing partnerships in the sustainable supply chain system. A predictive intelligence-based technique is important to ensure adequate supplier relationships. In this study, an ANFIS algorithm has been effectively used for SSS in a paint manufacturing company. This research study identifies the key sustainability factors in a paint manufacturing company (PMC) using the hybrid algorithm ANFIS in order to enhance sustainable efficiency. This study will therefore be useful in promoting the selection of suppliers not only in paint manufacturing companies, but also in other production and manufacturing systems.

\section{REFERENCES}

[1] Bai, C. \& Sarkis, J. 2018. Integrating sustainability into supplier selection: A grey-based TOPSIS analysis. Technological and Economic Development of Economy, 24(6), pp. 2202-2224. 
[2] Hassanzadeh, S. \& Cheng, K. 2016. Suppliers selection in manufacturing industries and associated multi-objective decision making methods: Past, present and the future. European Scientific Journal, 12(1), 1-12.

[3] Kushwaha, G.S. 2012. Operational performance through supply chain management practices. International Journal of Business and Social Science, 3(2),1-11.

[4] Ghoushchi, S.J., Milan, M.D. \& Rezaee, M.J. 2018. Evaluation and selection of sustainable suppliers in supply chain using new GP-DEA model with imprecise data. Journal of Industrial Engineering International, 14(3), pp. 613-625.

[5] Ertunc, H.M. \& Hosoz, M. 2008. Comparative analysis of an evaporative condenser using artificial neural network and adaptive neuro-fuzzy inference system. International Journal of Refrigeration, 31(8), pp. 1426-1436.

[6] Mukherjee, K. 2016. Supplier selection criteria and methods: Past, present and future. International Journal of Operational Research, 27(1-2), pp. 356-373.

[7] Webster, F.E. \& Wind, Y. 1996. A general model for understanding organizational buying behavior. Marketing Management, 4, pp. 52-57.

[8] De Boer, L., Van der Wegen, L. \& Telgen, J. 1998. Outranking methods in support of supplier selection. European Journal of Purchasing \& Supply Management, 4(2/3), pp. 109-118.

[9] Dobler, D.W. \& Burt, D.N. 1996. Purchasing and supply management. New York, NY: McGraw-Hill.

[10] Monczka, R., Handfield, R., Giunipero, L. \& Patterson, J. 2011. Purchasing and supply chain management. $5^{\text {th }}$ ed. Boston, MA: Cengage Learning.

[11] Van Weele, A.J. 2009. Purchasing \& supply chain management: Analysis, strategy, planning and practice. $5^{\text {th }}$ ed. Andover: Cengage Learning EMEA.

[12] Cousins, P., Lamming, R., Lawson, B. \& Squire, B. 2008. Strategic supply management: Principles, theories and practice. Harlow: Pearson Education.

[13] Ecer, F. \& Pamucar, D. 2020. Sustainable supplier selection: A novel integrated fuzzy best worst method (F-BWM) and fuzzy CoCoSo with Bonferroni (CoCoSo'B) multi-criteria model. Journal of Cleaner Production, 266, 1-18, 121981.

[14] Abdolazimi, O., Esfandarani, M.S., Salehi, M. \& Shishebori, D. 2020. Robust design of a multi-objective closedloop supply chain by integrating on-time delivery, cost, and environmental aspects, case study of a tire factory. Journal of Cleaner Production, 264, 1-15, 121566.

[15] Luthra, S., Govindan, K., Kannan, D., Mangla, S.K. \& Garg, C.P. 2017. An integrated framework for sustainable supplier selection and evaluation in supply chains. Journal of Cleaner Production, 140, pp. 1686-1698.

[16] Okwu, M.O. \& Tartibu, L.K. 2020. Sustainable supplier selection in the retail industry: A TOPSIS-and ANFIS-based evaluating methodology. International Journal of Engineering Business Management, 12,1-14. DOI:10.117/1847979019899542.

[17] Azadi, M., Jafarian, M., Saen, R.F. \& Mirhedayatian, S.M. 2015. A new fuzzy DEA model for evaluation of efficiency and effectiveness of suppliers in sustainable supply chain management context. Comput. Oper. Res., 54, pp. 274-285.

[18] Abdel-Baset, M., Chang, V., Gamal, A. \& Smarandache, F. 2019. An integrated neutrosophic ANP and VIKOR method for achieving sustainable supplier selection: A case study in importing field. Comput. Ind., 106, pp. 94110.

[19] Amoozad Mahdiraji, H., Arzaghi, S., Stauskis, G. \& Zavadskas, E. 2018. A hybrid fuzzy BWM-COPRAS method for analyzing key factors of sustainable architecture. Sustainability, 10(5), 1-59, 1626.

[20] Arabsheybani, A., Paydar, M.M. \& Safaei, A.S. 2018. An integrated fuzzy MOORA method and FMEA technique for sustainable supplier selection considering quantity discounts and supplier's risk. J. Clean. Prod., 190, pp. 577-591.

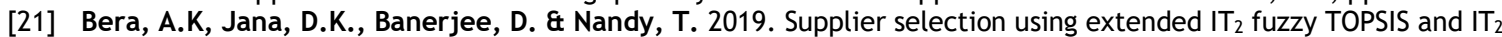
fuzzy MOORA considering subjective and objective factors. Soft Computing, 24, pp. $8899-8915$. https: / / doi.org/10.1007/s00500-019-04419-z

[22] Tirkolaee, E.B., Mardani, A., Dashtian, Z., Soltani, M. \& Weber, G. 2020. A novel hybrid method using fuzzy decision making and multi-objective programming for sustainable-reliable supplier selection in two-echelon supply chain design. Journal of Cleaner Production, 250, 119517.

[23] Arabsheybani, A., Paydar, M.M. \& Safaei, A.S. 2018. An integrated fuzzy MOORA method and FMEA technique for sustainable supplier selection considering quantity discounts and supplier's risk. J. Clean. Prod., 190, pp. 577-591.

[24] Okwu M.O., Chukwu V.U. and O. Oguoma (2019) Application of Artificial Neural Network Model for Cost Optimization in a Single, Multi-Destination System with Non-Deterministic Inputs. Advances in Computational Intelligence, Lecture Note in Computer Science book series (LNCS, Volume 11, 507) Springer. DOI:10.1007/978-3030-20518-8_45

[25] Amini, A., Alinezhad, A. \& Yazdipoor, F. 2019. A TOPSIS, VIKOR and DEA integrated evaluation method with belief structure under uncertainty to rank alternatives. International Journal of Advanced Operations Management, 11(3), pp. 171-188.

[26] Awasthi, A., Govindan, K. \& Gold, S. 2018. Multi-tier sustainable global supplier selection using a fuzzy AHP-VIKOR based approach. Int. J. Prod. Econ., 195, pp. 106-117.

[27] Azadeh, A., Zarrin, M. \& Salehi, N. 2016. Supplier selection in closed loop supply chain by an integrated simulation-Taguchi-DEA approach. J. Enterp. Inf. Manag., 29(3), pp. 302-326.

[28] Azimifard, A., Moosavirad, S.H. \& Ariafar, S. 2018. Selecting sustainable supplier countries for Iran's steel industry at three levels by using AHP and TOPSIS methods. Resources Policy, 57, pp. 30-44.

[29] Okwu, M.O. \& Adetunji, O. 2018. A comparative study of artificial neural network (ANN) and adaptive neuro-fuzzy inference system (ANFIS) models in distribution system with nondeterministic inputs. International Journal of Engineering Business Management, 10, pp. 1-17. DOI: 10.1177/1847979018768421 
[30] Oreko, B.U., Okiy, S., Uzorh, A.C. \& Oguoma, O. 2018. Artificial neural network model for cost optimization in a dual-source multi-destination outbound system. Cogent Engineering, 5, 1-13., 1447774. DOI: 10.13140/RG.2.2.35224.44804

[31] Abdulshahed, A.M., Longstaff, A.P. \& Fletcher, S. 2015. The application of ANFIS prediction models for thermal error compensation on CNC machine tools. Applied Soft Computing, 27, pp. 158-168.

[32] Mulvey, J.M., Vanderbei, R.J. and Zenios, S.A. (1995)"Robust optimization of large-scale systems", Operations Research 43, 264-281. 